Remigiusz ŻULICKI

Uniwersytet Łódzki

\title{
DOSTRZEC CZŁOWIEKA WYBRANE ZAGADNIENIA METODOLOGII BADAŃ SPOŁECZNYCH W SŁUŻBIE GEOGRAFII TURYZMU
}

\section{Przegląd metod i technik badań społecznych - „Turyzm/Tourism”}

Na potrzeby niniejszego tekstu dokonano przeglądu artykułów naukowych dostępnych w archiwum zeszytów czasopisma "Turyzm/Tourism”. Czasopismo to wybrano ze względu na tematykę publikowanych prac, skoncentrowaną wokół teorii turystyki. Celem kwerendy było ogólne rozpoznanie stosowanych przez autorów metod i technik badań społecznych oraz tego, w jaki sposób dobierane są one do problematyki. Spośród 62 artykułów opublikowanych w 10 zeszytach (2014, 24/2; 2014, 24/1; 2013, 23/2; 2013, 23/1; 2012, 22/2; 2012, 22/1; 2011, 21/1-2; 2010, 20/2; 2010, 20/1; 2009, 19/1-2) $\mathrm{w} 12$ pracach prezentowano i analizowano wyniki badań terenowych o charakterze społecznym. Rozumiemy przez to, że dane dotyczące m.in. ludzkich zachowań, opinii, postaw, planów, odczuć czy wrażeń zostały zebrane w terenie przez autora (lub dla niego) i że analiza tych pierwotnych danych była podstawą jego rozważań. W niemal wszystkich pozostałych pracach rozważaniom poddano rozmaite dane zastane, nawet gdy odwoływano się do wyników badań terenowych, a za takie uznać można np. dane GUS, analizowano gotowe wyniki, a nie dane surowe. $\mathrm{W}$ kilku pracach wykorzystano bada- 


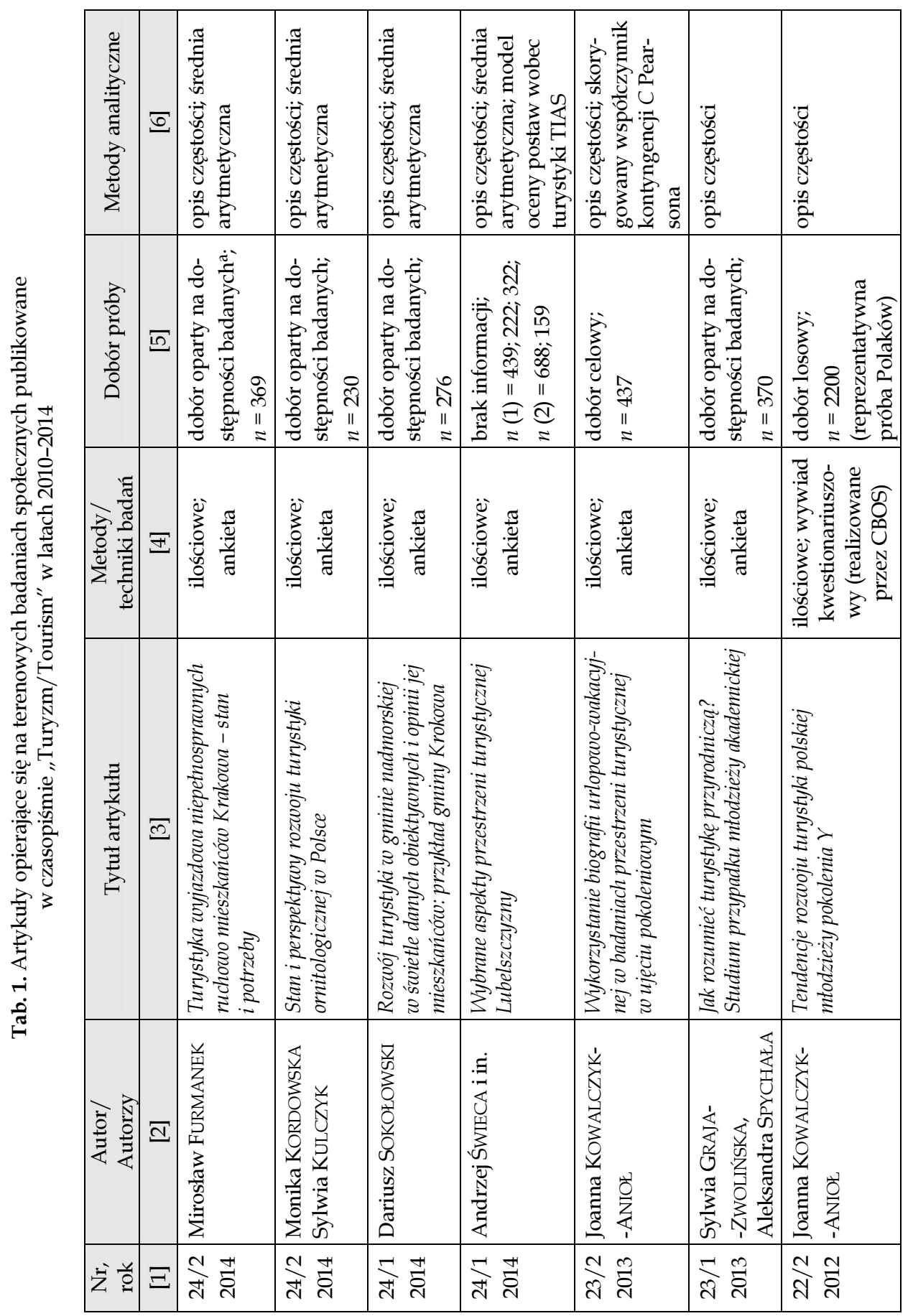




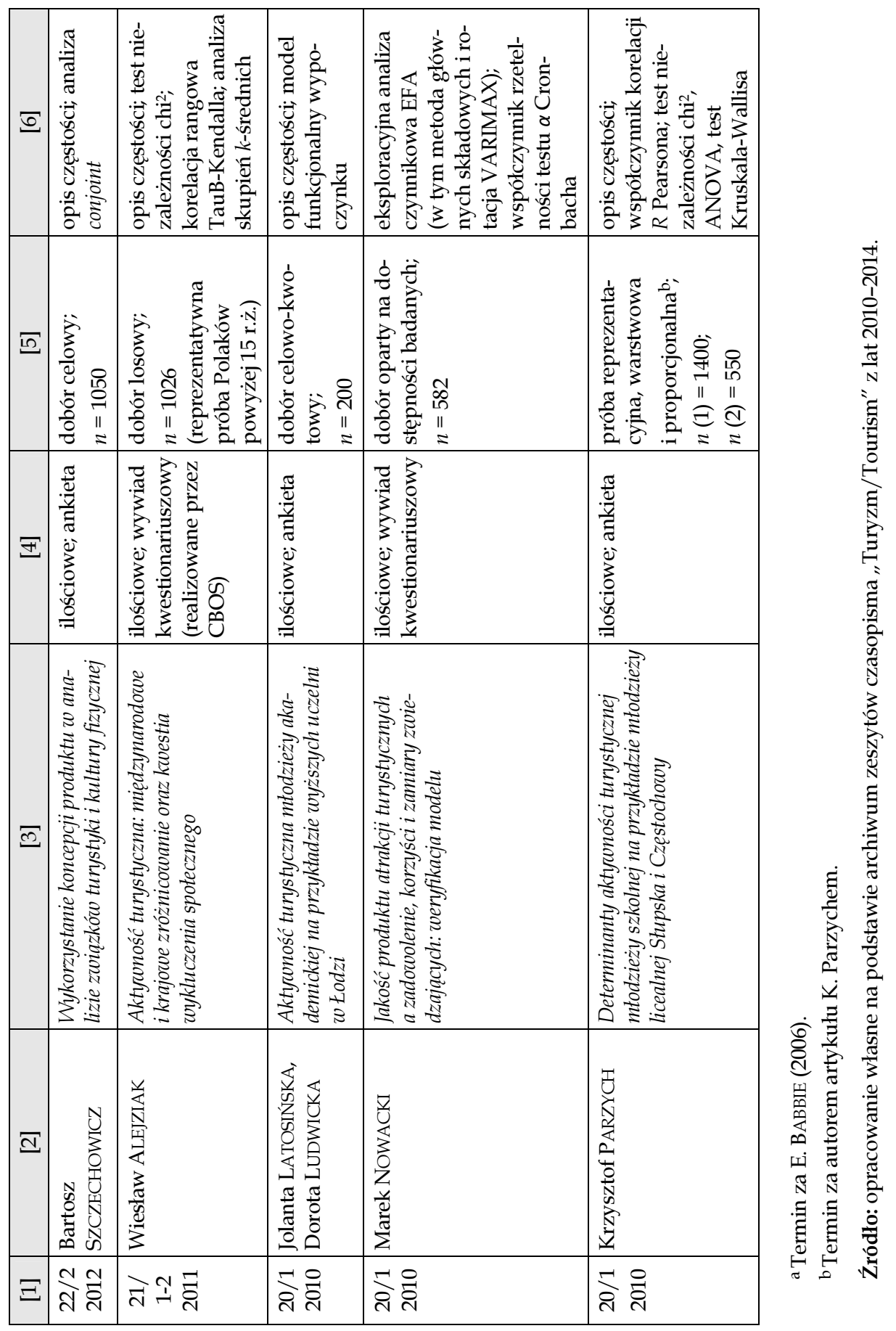


nia terenowe, które nie miały charakteru społecznego (hydrologiczne i inwentaryzacje). Wspomniane 12 artykułów powstałych na podstawie terenowych badań społecznych prezentowane są w tab. 1.

We wszystkich wymienionych $\mathrm{w}$ tab. 1 pracach posłużono się metodami ilościowymi i techniką ankiety albo wywiadu kwestionariuszowego. Pojęcia te zastosowano $\mathrm{w}$ niniejszym opracowaniu zgodnie $\mathrm{z}$ polską praktyką: ankieta oznacza formularz wypełniany samodzielnie przez respondenta, natomiast wywiad kwestionariuszowy wypełnia przeszkolony ankieter podczas zestandaryzowanej rozmowy z respondentem. Termin „kwestionariusz” rozumiany jest jako sam formularz, niezależnie od jego formy (elektroniczna czy papierowa) i tego, kto go wypełnia. Terminologią tą posługują się zarówno badacze marketingowi (NOGA-BOGOMILSKI 2007), jak i „klasycy” metodologii badań społecznych (LUTYŃSKI 1972). Ankieta i wywiad kwestionariuszowy należą do wysokostandaryzowanych technik otrzymywania materiałów. Choć metodologowie zwracają uwagę na wpływ tego, czy komunikacja badanego z badaczem jest pośrednia czy bezpośrednia, jaki charakter ma ewentualne zapośredniczenie, a także w jakim stopniu ankieter uczestniczy w procesie badawczym, w tym opracowaniu poruszymy jedynie wybrane aspekty konstruowania narzędzi stosowanych we wspomnianych wysokostandaryzowanych technikach. Charakterystykom poszczególnych technik (m.in. CATI, CAPI, PAPI, CAWI, CASI; ankiecie audytoryjnej, indywidualnej pod nadzorem, socjometrycznej, pocztowej) ${ }^{1} \mathrm{w}$ wymiarach wpływu charakteru komunikacji i wpływu ankieterskiego na uzyskiwany materiał badawczy poświęcono wiele znakomitych publikacji² ${ }^{2}$.

\section{Metody badań ilościowych - techniki wysokostandaryzowane}

Jak zatem konstruować wysokostandaryzowane narzędzia badawcze? Pytanie to dotyczy zarówno konstrukcji oraz treści pytań, jak i budowy całego kwestionariusza. Warto zwrócić szczególną uwagę na to, że charakter pozys-

${ }^{1}$ CATI - computer assisted telephone interview (wywiad telefoniczny wspomagany komputerowo), CAPI - computer assisted personal interview (wywiad bezpośredni wspomagany komputerowo), PAPI - paper and pen personal interview (wywiad bezpośredni z użyciem kwestionariusza papierowego), CAWI - computer assisted web interview (ankieta internetowa/ankieta email), CASI - computer assisted self interviewing (ankieta wypełniania na komputerze ankietera).

2 Por. m.in.: K. GRZESZKIEWICZ-RADUlSKA, A. KRZEWIŃSKA (2013), A. KUBIAK, W.A. ROSTOCKI (1993), K. LUTYŃSKA (1997), H. SCHUMAN (2013), P.B. SZTABIŃSKI (1996). 
kanych danych ma kluczowe znaczenie dla możliwości ich późniejszego przetwarzania. W konsekwencji waży to na jakości formułowanych wniosków. Istotnym zagadnieniem jest więc poziom pomiaru zmiennych: nominalny, porządkowy, interwałowy czy ilorazowy (NAWOJCZYK 2002, FRANCUZ, MACKIEWICZ 2005). Oczywiste jest, że w przypadku zmiennych mierzonych na poziomie nominalnym, takich jak płeć, województwo zamieszkania czy destynacja wyjazdu wakacyjnego, nie jest możliwe wykonywanie działań arytmetycznych. Kategoriom tych zmiennych przypisujemy wartości liczbowe na potrzeby kodowania (np. płeć: 1 - kobieta, 2 - mężczyzna), jednak wartości te nie mają "sensu”. Można wykonać zliczenie wystą̧ień poszczególnych wartości i opisać częstość wystąpienia odpowiedzi, ale nie wykonuje się żadnych działań arytmetycznych. Ten poziom pomiaru bywa nazywany jakościowym ${ }^{3}$. Zmienne jakościowe mogą być traktowane jako czynnik - zmienna niezależna - i służyć analizie zróżnicowania zmiennej zależnej mierzonej na wyższych poziomach. Przykład takiej procedury analitycznej stanowi ANOVA. Wydaje się, że zasadniczo warto stawiać respondentowi pytanie $w$ taki sposób, by uzyskać możliwie najwyższy poziom pomiaru, jednak nie należy traktować tego jako regułę, a dobierać miarę zmiennej do celów badania (FRANCUZ, MACKIEWICZ 2005). Niewątpliwie jednak utrata możliwości wykonania pewnych operacji z powodu niewłaściwego poziomu pomiaru będzie niekorzystna. Przykładem bliskim badaniom nad turystką jest pytanie o liczbę wyjazdów/długość wyjazdów - najwyższy, ilorazowy poziom pomiaru uzyskamy prosząc badanych o podanie konkretnej liczby. Tworząc pytanie z kafeterią, która może odzwierciedlać przyjęte kategorie analityczne, takie jak wyjazdy krótkoterminowe (1-4 dni) i długoterminowe (powyżej $5 \mathrm{dni}$ ) (PARZYCH 2010), redukujemy poziom pomiaru zmiennej, a w konsekwencji zubażamy wnioski. Tworzenie zmiennych porządkowych czy nominalnych na podstawie mierzonych na poziomach ilościowych ${ }^{4}$ jest jednak użyteczne np. przy ilustrowaniu charakterystyki danej populacji. Tworząc tabelę częstości dla zmiennej „dochód” czy "wiek" w taki sposób, że każda wartość stanowi kategorię, łatwo doprowadzić czytelnika do zagubienia. Skategoryzowanie wieku/dochodu w przedziały czyni te informacje bardziej przystępnymi.

Powyżej przedstawiono zagadnienie „utrzymania” ilościowego poziomu zmiennej. Co w sytuacji, gdy problematyka badania wymaga pomiaru posta-

${ }^{3}$ Taki termin funkcjonuje $\mathrm{w}$ programie SPSS.

${ }^{4}$ Tak w SPSS są nazwane zmienne mierzone na poziomie interwałowym i ilorazowym. 
wy czy sympatii? W przeciwieństwie do wymienionych przykładów żadna z nich nie jest potocznie wyrażana w sposób ilościowy. Możliwe jest postawienie pojedynczego pytania: "Jaka jest Pani/Pana sympatia względem wzrostu ruchu turystycznego w gminie X?" i udostępnienie kafeterii w postaci skali pięcio- czy dziesięciostopniowej. Powstaje od razu pytanie o wiarygodność uzyskanej odpowiedzi. Już w latach 70. minionego stulecia J. Lutyński zwrócił uwagę na to, że w przypadku deklaracji, a tym byłaby odpowiedź badanego na przykładowe pytanie, wiarygodność może okazać się wątpliwa. W przytoczonym przykładzie porównano odpowiedzi dotyczące pobytu w szpitalu z danymi rejestrowymi tej placówki. W niektórych przekrojach odsetek osób, które faktycznie przebywały w szpitalu, a na pytanie o fakt pobytu odpowiedziały przecząco, wyniósł prawie 60\% (LUTYŃSKI 1972). Mogło to być spowodowane nie tyle nieszczerością, co pewnymi cechami ludzkiej pamięci - częściej udzielano „błędnej” odpowiedzi w przypadku pobytów krótkich lub odległych w czasie (LUTYŃSKI 1972).

Specyficzne dla badań społecznych, a właściwie dla ludzi, są także dysonanse między deklarowaną własnością (np. samą definicją jako osoby o poglądach prawicowych) a postawą (poglądami czy odczuciami, które wyrażono przy okazji innych pytań) oraz zachowaniem (tu np. głosowaniem na partię lewicową) (NAWOJCZYK 2002). Obecnie pod uwagę brana jest również możliwość udzielania odpowiedzi ironicznych, ponieważ rozumienie ironii ma być rodzajem kompetencji kulturowej, charakterystycznej dla wielkomiejskiego życia (SZLENDAK 2015). W jaki sposób badacz społeczny może więc "przechytrzyć" badanego? W przypadku badania postaw jedną ze strategii jest tworzenie indeksów. Ogólna logika indeksów polega na tym, że tworzymy pewną liczbę pytań, które odpowiadają wymiarom bardziej złożonej zmiennej (NAWOJCZYK 2002). Badając postawy wobec wzrostu ruchu turystycznego w gminie $X$ można poprosić respondentów o ustosunkowanie się do stwierdzeń, takich jak np.: (A) „Dzięki turystom mogę uzyskać dodatkowy dochód”; (B) „Generalnie nie lubię obecności turystów w mojej miejscowości”; (C) „Większa liczba turystów oznacza niszczenie lokalnej przyrody”; (D) „Władze gminy powinny wspierać głównie lokalnych przedsiębiorców z branży turystycznej”; (E) „Należy promować gminę X jako doskonałe miejsce na wakacje". Tradycyjnym narzędziem w badaniu postaw jest pięciostopniowa skala Likerta, od „zdecydowanie nie” - 1, do „zdecydowanie tak” - 5, z punktem środkowym - 3. W zaprezentowanym uproszczonym przykładzie, przypisując każdej kategorii odpowiedzi liczbę 
punktów ${ }^{5}$ i sumując te punkty dla każdego rekordu, tworzymy indeks postawy wobec wzrostu ruchu turystycznego. Dla osoby o nastawieniu skrajnie pozytywnym wartość indeksu wyniesie 100 pkt. By uniknąć niekorzystnych efektów, jakim byłoby bezrefleksyjne i rutynowe zaznaczanie tylko jednego bieguna odpowiedzi, można zastosować różne konstrukcje pytań. Wyrażana zgoda lub jej brak oznacza raz nastawienie pozytywne, raz przeciwne - w zależności od konstrukcji. Wartości tak utworzonego indeksu traktowane są jako ilościowy (interwałowy) poziom pomiaru (NAWOJCZYK 2002). Tak wygląda praktyka badawcza nauk społecznych, choć faktycznie decyzja o przyznawaniu punktów w interwale 5 każdemu ze stopni skali Likerta jest decyzją arbitralną badacza. Wskazuje się, że większa liczba pytań składających się na indeks „zbliża” wartość indeksu do pomiaru na poziomie interwałowym (NAWOJCZYK 2002). Niewątpliwie zapewnia to większą ciągłość wartości indeksu. Gdyby nastawienie skrajne oznaczała wartość 100 pkt., to przy 20 pytaniach składowych można uzyskać wynik w interwale 1 pkt; analogicznie przy 10 pytaniach interwał to 2 pkt., przy 5 - 5 pkt. Spory dotyczące przejścia $\mathrm{z}$ poziomu porządkowego do interwałowego trwają wśród badaczy już około 60 lat (FRANCUZ, MACKIEWICZ 2005). Ostateczna decyzja co do interpretacji i sposobu traktowania uzyskanych czy „nadanych" liczb należy wyłącznie do badacza.

Stworzony indeks można rozpatrywać w kategoriach trafności i rzetelności. Trafność rozumiana jest jako stopień zgodności tego, co planowano zmierzyć z tym, co mierzy dany indeks (NAWOJCZYK 2002). Trafność zależy w dużej mierze od tego, jak została wykonana konkretyzacja i operacjonalizacja kluczowych pojęć. W pracy Statystyka. Wprozvadzenie do analizy danych sondażowych $i$ eksperymentalnych uznano, że nie można ocenić trafności indeksu czy wskaźnika bez dodatkowych danych (WIECZORKOWSKA-WIERZBIŃSKA 2005). Mowa tu o tzw. trafności empirycznej; jej ocena w uproszczeniu polega na porównaniu wyników badania z innym wynikiem bądź stanem faktycznym - podobnie jak w przykładzie dotyczącym pobytu w szpitalu. Rzetelność, rozumianą jako wewnętrzną spójność i stabilność skonstruowanej miary, można ocenić bez danych zewnętrznych (NAWOJCZYK 2002, WIECZORKOWSKA-WIERZBIŃSKA 2005). Różnicę między trafnością a rzetelnością dobrze oddaje porównanie pomiaru do strzelania z łuku. Indeks jest trafny, kiedy strzały trafiły tam, gdzie mierzono. Jest rzetelny, gdy na tarczy są po-

\footnotetext{
${ }^{5}$ Dla pytań A, D, E: 1 - 0; 2 - 5; 3 - 10; 4 - 15; 5 - 20; dla pytań B i C w sposób odwrotny.
} 
łożone blisko siebie (WIECZORKOWSKA-WIERZBIŃSKA 2005). Popularną ${ }^{6}$ miarą rzetelności indeksów jest współczynnik $\alpha$ Cronbacha. Mierzy on stosunek sumy wariancji pytań tworzących indeks do wariancji sumarycznej, czyli wariancji wartości indeksu. Jeżeli poszczególne pytania mierzą faktycznie tę samą zmienność, to suma ich wariancji będzie większa niż wariancja sumaryczna. Wzór $\alpha$ Cronbacha zapisać można następująco:

$$
\alpha=\frac{k}{k-1}\left(1-\frac{\sum_{i=1}^{k} s_{i}^{2}}{s_{c}^{2}}\right),
$$

gdzie:

$k$ - liczba pozycji (pytań tworzących indeks),

$s_{c}^{2}-$ wariancja sumaryczna (wartości indeksu),

$\sum_{i=1}^{k} s_{i}^{2}$ - suma wariancji pozycji.

Jeśli pytania tworzące indeks w ogóle nie dają wyniku "prawdziwego”, wtedy wariancja sumaryczna będzie taka jak suma wariancji poszczególnych pytan; w konsekwencji $\alpha$ będzie równe 0 . Gdyby wszystkie pytania były idealnie rzetelne i mierzyły to samo wówczas $\alpha=1$. Za rzetelne zazwyczaj uznaje się indeksy/testy, gdzie $\alpha>0,7$. Omówiony wskaźnik jest jednym z najlepszych do szacowania rzetelności (HORNOWSKA 2010). Poza jasną interpretacją do jego zalet należy łatwość w określaniu, która pozycja „działa” zgodnie z intencją badacza. W programach SPSS czy Statistica dostępna jest informacja o wartości $\alpha$, gdy usuniemy daną pozycję, co stanowi dla badacza cenną wskazówkę (WIECZORKOWSKA-WIERZBIŃSKA 2005). Rzetelność zwiększać można także dzięki przeprowadzeniu badania pilotażowego ${ }^{7}$, jak i pomijaniu w gotowym materiale badawczym analizy pozycji źle skonstruowanych. Inną drogą jest tworzenie indeksów na podstawie kategorii wyłonionych w toku badań jakościowych, o czym jeszcze wspomnimy.

\section{Myślenie statystyczne = myślenie naukowe?}

Wracając do wykonanej kwerendy 62 artykułów opublikowanych w latach 2009-2014 w czasopiśmie „Turyzm/Tourism” warto zauważyć, że spośród $50 \mathrm{z}$ nich, w których nie wykonywano/nie analizowano danych $\mathrm{z}$ tereno-

\footnotetext{
${ }^{6}$ Zastosowany również przez M. NOWACKIEGO (2010) w artykule Jakość produktu atrakcji turystycznych....

${ }^{7}$ Na przykład na próbie opartej na dostępności badanych (BABBIE 2006).
} 
wych badań społecznych, w 34 przynajmniej odnoszono się do danych liczbowych. Oznacza to, że w sumie $46^{8}$ z 62 prac odnosi się do charakterystyk kwantyfikowalnych. Pozostałe 16 artykułów to opracowania teoretyczne bądź historyczne, gdzie odniesienia dotyczą opisanych $\mathrm{w}$ literaturze teorii i faktów. Abstrahując od tematyki artykułów i mając świadomość potocznego charakteru wykonanej obserwacji można odnieść wrażenie, że w refleksji nad turystyką dominuje podejście ilościowe. Być może właśnie na tym polega nauka w ogóle? Wszak już pod koniec XVII wieku Arbuthnot stwierdził, że: „Niewiele spośród znanych nam rzeczy nie da się sprowadzić do Rozumowania Matematycznego; a jeśli tak się dzieje, jest to znak, że nasza Wiedza o nich jest niewielka i nieuporządkowana" (OSTASIEWICZ 2012). Zwracamy uwagę na fakt używania rozmaitych metod kwantyfikacji w geografii turyzmu i w naukach społecznych. W pierwszej dziedzinie występują m.in. intensywność ruchu turystycznego w świetle wskaźnika Chavrata, współczynnik atrakcyjności turystycznej według J. Warszyńskiej (RYDZ 2014), SMAT - syntetyczny miernik atrakcyjności turystycznej, Tfffl - wskaźnik miejsc noclegowych Barette'a Deferta (ŚWIECA i in. 2014); miernik syntetyczny Ft według procedury Z. Zioły (SОВOTKA 2014). W drugiej dziedzinie, odgrywając rolę służebną wobec badań turystyki występuje np. model TIAS - skala postaw wobec turystyki (ŚwIECA i in. 2014), czy ogólnie wszelkiego rodzaju indeksy podobne do uproszczonego przykładu podanego $w$ niniejszej pracy. Procedury analityczne, takie jak ocena rzetelności testu czy wspomniana ANOVA odzwierciedlają tzw. pierwszą zasadę myślenia statystycznego. Według tejże obserwowane aspekty świata są połączeniem dwóch bytów idealnych: wielkości stabilnej i wielkości losowej. W nauce staramy się z obserwacji wydobyć i opisać element stabilny (regularny) (OSTASIEWICZ 2012). Na tym właściwie opiera się np. logika ANOVA - na mierzeniu tego, jaka część wariancji zmiennej zależnej jest wyjaśniona przez zadany czynnik, a jaka jest wynikiem błędu (losowego bądź będącego skutkiem innego, nieznanego czynnika). Ponieważ „natura jest skomplikowana, ale złośliwości nam nie wykazuje, możemy więc ją poznawać, jeśli nawet tylko do pewnego stopnia" (OSTASIEWICZ 2012). Duża liczba pomiarów sprawia, że możliwe jest wykrycie prawidłowości rzeczywiście istniejących w naturze (OSTASIEWICZ 2012). O ile natura nie wykazuje owej „złośliwości”, to swego rodzaju „złośliwość" wykazują badani ludzie. Nie chodzi wyłącznie o działania intencjonalne - fakt, że badani i badacz są ludźmi powoduje liczne na-

834 desk research i 12 field research. 
stępstwa. Dlatego podejście do badań społecznych, tak jak do badań przyrodniczych, jest jedną z dwóch niedoskonałych możliwości, nazywanych paradygmatem normatywnym i interpretatywnym. Pierwszy z nich można skrótowo opisać jako model poznania właściwy naukom przyrodniczym badacz jest obiektywnym, zewnętrznym obserwatorem odkrywającym prawidłowości tego co jest. Drugi z paradygmatów zakłada, że badacz i badany występują zawsze jako „pełny człowiek”, z całym uświadomionym i nieuświadomionym zapleczem kulturowym, a świat społeczny jest konstruowany $\mathrm{i}$ interpretowany $\mathrm{w}$ toku interakcji. Bliższe paradygmatowi interpretatywnemu są metody badań jakościowych i niskostandaryzowane techniki otrzymywania materiałów.

\section{Metody jakościowe - techniki niskostandaryzowane}

Chyba najbardziej popularną techniką w jakościowych badaniach społecznych są wywiady swobodne ukierunkowane (PRZYBYŁOWSKA 1978). Wywiad tego typu jest prowadzony według przygotowanych wcześniej dyspozycji, które są ogólnie określoną listą potrzeb informacyjnych badacza. Można przygotować wzory pytań do ewentualnego użycia podczas wywiadu. Prowadzący ma dużą swobodę w formułowaniu pytań. Pytania powinny być otwarte i dotyczyć zagadnień szczegółowych, jednocześnie odwołując się do doświadczenia rozmówcy. W sytuacji wywiadu badacz dostosowuje treść i język pytań do rozmowy partnera. Zapis może być rejestrujący lub relacjonujący Można rozróżnić wywiady ze względu na cel: rozpoznawanie zjawiska albo sprawdzanie hipotez (KONECKI 2000). Wydaje się, że w artykule Stan i perspektywoy rozwoju turystyki ornitologicznej w Polsce podjęto próbę rozpoznania zjawiska za pomoca potocznych procedur poznawczych o charakterze jakościowym. W akapicie poświęconym metodom badań napisano: „Na podstawie obserwacji terenowych, aktywnego uczestnictwa w wycieczkach ornitologicznych, rozmów z ich organizatorami i uczestnikami $^{9}$ oraz danych $\mathrm{z}$ badania kwestionariuszowego opisano sylwetkę polskiego turysty ornitologa." (KORDOWSKA, KULCZYK 2014). Uczestnictwo w wycieczkach przywodzi na myśl etnograficzne metody badań, takie jak obserwacja uczestnicząca. Wywiady zaś właściwie są rozmowami o ustalonych ramach. Tego rodzaju eksploracyjne korzystanie $\mathrm{z}$ metod i technik

\footnotetext{
${ }_{9}^{9}$ Podkreślenie R.Ż.
}

60

WARSZTATY Z GEOGRAFII TURYZMU 
badań jakościowych może być wstępem np. do konkretyzacji i operacjonalizacji pojęć w głównym badaniu ilościowym. Jest to również wartościowa metoda poszukiwania kategorii zmiennych czy pozycji mających tworzyć indeksy - wówczas mają one pewne umocowanie empiryczne, nie opierają się wyłącznie na przeglądzie literatury czy opiniach ekspertów. Fakt ten może być pomocny w uzyskaniu trafności i rzetelności wysokostandaryzowanego narzędzia badawczego. Oczywiście istnieje możliwość przeprowadzenia jakościowego projektu badawczego osadzonego w paradygmacie interpretatywnym. Tego typu projekt mógłby koncentrować się np. na rozumieniu lub próbie rekonstrukcji procesu stawania się turystą kwalifikowanym. Wracając na grunt wywiadu swobodnego uznaje się, że wywiad to rozmowa, w której dane są współtworzone; rodzą się w relacji przeprowadzającego z udzielającym. Narzędziem badawczym w badaniach jakościowych jest osoba prowadząca badanie (tu: wywiad) (KONECKI 2000). Wywiad nie jest metodą obiektywną ani subiektywną; jego istotą jest interakcja międzyosobowa (KVALE 2004). Tego typu technika, w której prowadzący luźno zgłębia wybrane tematy, nazywana jest wywiadem intensywnym (CHARMAZ 2009). Pod względem praktycznym może być on tożsamy z wywiadem swobodnym ukierunkowanym. Prowadzący ma przygotowaną listę potrzeb informacyjnych, $\mathrm{w}$ trakcie wywiadu zgłębia tematy dochodząc do zagadnień szczegółowych, pytania zadaje w sposób niestandaryzowany. Autorka akcentuje możliwość uzyskania od uczestnika jego interpretacji doświadczeń. Uczestnik jest traktowany jak ekspert $\mathrm{w}$ danej dziedzinie (CHARMAZ 2009).

Niezwykle istotne jest etyczne prowadzenie wywiadów. Jakiekolwiek nieetyczne zachowanie badacza jest nie tylko wątpliwe moralnie, ale też niekorzystne dla uzyskanych wniosków - rujnuje się tym zaufanie badanego i może, np. w przypadku badania ekskluzywnej grupy, dojść do kompletnej porażki. Niemniej nawet wywiad swobodny przeprowadzony etycznie jest rodzajem relacji niesymetrycznej. Asymetria ta dotyczy też z pewnością technik ankietowych i wywiadów kwestionariuszowych. K.T. Konecki przedstawił przejście od rozumienia „interview" jako „roz-mawiania”, czyli sytuacji łączącej partnerów w relacji symetrycznej, do rozumienia jako „wywiad”, co w języku polskim oznacza szpiegowanie bądź instytucję szpiegowską. Przekłada się to $w$ konsekwencji na prowadzenie wywiadów jako przesłuchania czy odpytywania. Szczególnym momentem asymetrii jest rozstanie się uczestnika i prowadzącego - pierwszy uboższy o swoją prywatność, odsłonięty i "nagi”, drugi bogatszy o pożądane informacje. Proponuje się więc, 
by prowadząc wywiady swobodne wykazywać się empatią, starać się o wzajemne zaufanie i naturalność sytuacji. Wywiad ma zbliżać się do rozmowy, która „odbywa się w naturalnym kontekście potocznego życia i pracy osób objętych naszym badaniem." (KONECKI 2000).

By rzetelnie przeprowadzić wywiad, należy ustalić jego ramy. Sposobem na to jest podanie uczestnikowi jasnych instrukcji, w których omówimy krótko kontekst wywiadu. Przed wywiadem należy zdefiniować sytuację, wskazać do jakich celów badanie będzie wykorzystane, omówić anonimowość, kwestię dostępu do publikacji wywiadu, kwestię rejestracji wywiadu, uzyskać świadomą zgodę, odpowiedzieć na ewentualne pytania przed rozpoczęciem nagrania. Jest to instrukcja przed wywiadem. Dalsze wyjaśnienia co do wywiadu i badania można przedstawić w instrukcji po wywiadzie. Wywiad należy wyraźnie kończyć, np. „Nie mam już dalszych pytań. Czy chce Pani/Pan coś dodać lub zapytać, zanim skończymy wywiad?". Po wyłączeniu nagrywania, jeśli uczestnik jest zainteresowany, można porozmawiać jeszcze o temacie badania czy też samym badaniu (KVALE 2004). Tak zwana instrukcja po wywiadzie redukuje nieco mogące się pojawić w badanym poczucie napięcia czy pustki, zbliża też wywiad do rozmowy towarzyskiej.

Analiza materiału jakościowego nie ma charakteru ilościowego, jednak procedurą techniczną w procesie analizy jest kodowanie. Generalnie jest ono wydobywaniem kategorii i ich własności z materiałów jakościowych. Kodowanie jest rozumiane inaczej niż w badaniach ilościowych; nie kategoryzuje się danych przyjętym kluczem, a kategorie z tychże danych się wyprowadza (KVALE 2004). Jednym z bardziej precyzyjnych podejść do analizy danych jakościowych, a szerzej - do systematycznego odkrywania teorii na podstawie jakościowych badań terenowych, jest metodologia teorii ugruntowanej (MTU). Według K. CHARMAZ (2009), socjolożki posługującej się MTU, „kodowanie to główne ogniwo między zbieraniem danych a budowaniem wyłaniającej się teorii, które ma na celu wyjaśnienie tych danych. Poprzez kodowanie można zdefiniować to, co dzieje się w danych, i zacząć rozszyfrowywać znaczenie tych faktów." Glaser i Strauss, pionierzy MTU, zwracali uwagę na to, by kodowanie nie było jedynie nazwaniem kategorii, a uwzględniało takie elementy, jak: zjawisko; warunki przyczynowe wystąpienia badanego zjawiska; kontekst, rozumiany jako czas, miejsce i przestrzeń zdarzeń na zjawisko się składających; warunki interweniujące, czyli strukturalne czynniki wpływu na interakcje i działania odnoszące się do zjawiska; działania/interakcje; techniki interakcyjne jako konkretne zachowania; konsek- 
wencje działań oraz interakcji (KONECKI 2000). MTU jest uznawana za metodologię naturalistyczną, co oznacza $w$ tym przypadku stosowanie badań terenowych, głównie obserwacji bezpośredniej, jak w zoologii czy archeologii. Badacz stosujący MTU widzi jednak świat nie mechanistycznie a humanistycznie, czyli interpretatywnie. Perspektywa ta jest skoncentrowana na "kształtowanych symbolicznie ludzkich procesach poznawczych" (KONECKI 2000), których badanie jest drogą do objaśniania oraz zrozumienia rzeczywistości. W procesie kodowania teoria jest odkrywana $\mathrm{z}$ materiału empirycznego. Istnieje wiele programów komputerowych wspomagających kodowanie i analizę materiałów jakościowych. Określane są one akronimem CAQUDAS ${ }^{10}$. Programy takie, jak np. OpenCode, WeftQDA, CmapTools (bezpłatne) czy NVivo, Atlas.ti, MaxQDA (najpopularniejsze komercyjne) ułatwiają kodowanie i nawigację $\mathrm{w}$ tekście i kodach różnych poziomów. Istnieją możliwości tworzenia pomocnych dla badacza wizualizacji, jak np. drzewo kategorii czy mapowanie pojęć (NIEDBALSKI 2013). Zakres, charakter i materiał analizy zależy oczywiście od badacza - można korzystać z oprogramowania CAQUDAS, m.in. do wspomagania analizy treści przewodników turystycznych (LISZEWSKI 2014).

\section{Zagadnienie doboru metodologii do badanej problematyki}

Metody, techniki i materiały pochodzące $\mathrm{z}$ badań ilościowych i jakościowych mogą być $z$ powodzeniem stosowane $w$ jednym projekcie badawczym. Wiąże się z tym pojęcie triangulacji. Wyróżniono triangulację danych, metod oraz technik. Triangulacja ma na celu szersze uchwycenie interesującego nas wycinka rzeczywistości, ogląd różnych perspektyw, wzajemne wzbogacanie i weryfikację uzyskiwanych wniosków. Ma prowadzić do zminimalizowania błędów i ograniczeń związanych z podejściem jednostronnym. Używanie różnych technik, metod i źródeł danych jest więc strategią, która - używając określenia wartościującego - może uczynić, że wnioski będą bardziej trafne poprzez efekt swoistej synergii. Istnieje jednak postulat nie przekraczania granic paradygmatów (normatywnego i interpretatywnego), co ma być uzasadnione ich odmiennymi założeniami ontologicznymi. Zdaniem niektórych uczonych różnice dotyczące podstawowych założeń co do własności rzeczywistości społecznej, które można zredukować do pojęć „istniejąca” vs. „kon-

${ }^{10}$ Computer assisted qualitative data analysis software. 
struowana", sprawiają że w jednym projekcie należy wybrać jedno z podejść (KONECKI 2000). Istnieje jednak pojęcie trzeciej drogi metodologicznej, trzeciego paradygmatu czy trzeciego ruchu metodologicznego dążącego do integracji paradygmatów na różnych poziomach (CHLIPAŁA 2013).

W tab. 2. zaprezentowano skrótowe zestawienie najważniejszych charakterystyk metod badań społecznych.

Tab. 1. Metody badań społecznych

\begin{tabular}{|l|l|}
\hline \multicolumn{1}{|c|}{$\begin{array}{c}\text { Metody badań } \\
\text { ilościowych }\end{array}$} & \multicolumn{1}{c|}{$\begin{array}{c}\text { Metody badań } \\
\text { jakościowych }\end{array}$} \\
\hline \multicolumn{2}{|c|}{ Możliwości epistemologiczne } \\
\hline $\begin{array}{l}\mid \\
\text { - Opis statyczny }\end{array}$ & - Opis statyczny \\
- Pomiar: określanie wielkości poziomu, & - Opis procesu \\
określanie czynników wpływu; miary & - Rozumienie \\
siły związku; miary kierunku związku & - Odkrywanie nowych zagadnień \\
- Porównywanie grup/szeregów & - Rozpoznanie \\
czasowych & \\
- Prognozowanie/modelowanie & - wywiad indywidualny \\
\hline- ankieta & - zogniskowany wywiad grupowy \\
- test & - obserwacja \\
- wywiad kwestionariuszowy & \\
\hline
\end{tabular}

Źródło: opracowanie własne na podstawie literatury przedmiotu.

Zestawienie to jest skrótowe i schematyczne; ma służyć ilustracji różnic w możliwościach zastosowań obu metod. Autor chciałby życzyć wszystkim badającym rzeczywistość społeczną dokonywania twórczych wyborów metodologicznych, przy jednoczesnym zachowaniu wrażliwości na specyfikę badań. Wszystko po to, by jak najlepiej dostrzec człowieka.

\section{Bibliografia}

ALEJZIAK W., 2011, Aktywność turystyczna: międzynarodowe i krajowe zróżnicowanie oraz kwestia wykluczenia społecznego, "Turyzm/Tourism”, 21/1-2, s. 7-16.

BABBIE E., 2006, Badania społeczne w praktyce, Wyd. Naukowe PWN, Warszawa.

CHARMAZ K., 2009, Teoria ugruntowana. Praktyczny przewodnik po analizie jakościowej, Wyd. Naukowe PWN, Warszawa.

CHLIPAŁA P., 2013, Orientacja hybrydowa a nowe podejścia w marketingu, "Zeszyty Naukowe UEK": Metody analizy danych, 916, s. 25-35. 
FRANCUZ P., MACKIEWICZ R., 2005, Liczby nie wiedza, skąd pochodza. Przewodnik po metodologii i statystyce nie tylko dla psychologów, Wyd. KUL, Lublin.

FURMANEK M., 2014, Turystyka wyjazdowa niepetnosprawnych ruchowo mieszkańców Krakowa - stan i potrzeby, "Turyzm/Tourism” 24/2, s. 7-15.

GRAJA-ZWOLIŃSKA S., SPYCHAŁA A., 2013, Jak rozumieć turystykę przyrodniczą? Studium przypadku mtodzieży akademickiej, „Turyzm/Tourism”, 23/1, s. 39-47.

GRZESZKIEWICZ-RADULSKA K., KRZEWIŃSKA A., 2013, Klasyfikacja sondażowych technik otrzymywania materiatów, „Przegląd Socjologiczny", 62/1, s. 9-31.

HORNOWSKA E., 2010, Testy psychologiczne. Teoria i praktyka, Wyd. Naukowe Scholar, Warszawa.

KONECKI K.T., 2000, Studia z metodologii badań jakościowych. Teoria ugruntowana, Wyd. Naukowe PWN, Warszawa.

KORDOWSKA M., KULCZYK S., 2014, Stan i perspektywy rozwoju turystyki ornitologicznej w Polsce, „Turyzm/Tourism", 24/2, s. 17-24.

KOWALCZYK-ANIOŁ J., 2012 Tendencje rozwoju turystyki polskiej mtodzieży pokolenia Y, „Turyzm/ Tourism", 22/2, s. 15-21.

KOWALCZYK-ANIO૯ J., 2013, Wykorzystanie biografii urlopowo-wakacyjnej w badaniach przestrzeni turystycznej w ujęciu pokoleniowym, „Turyzm/Tourism”, 23/2, s. 15-22.

KUBIAK A., ROSTOCKI W.A., 1993, Metodologiczne problemy badania opinii publicznej w Polsce. Społeczna przestrzeń wywiadu kwestionariuszowego, „Przegląd Socjologiczny”, XL/2.

KVALE S., 2004, InterViews. Wprowadzenie do jakościowego wyjwiadu badawczego, Trans Humana, Białystok.

LATOSIŃSKA J., LUDWICKA D., 2010, Aktywność turystyczna młodzieży akademickiej na przyktadzie wyższych uczelni w Łodzi, „Turyzm/Tourism”, 20/1, s. 21-28.

LisZEWSKI S., 2014, Miejska przestrzeń turystyczna. Metody badań. Ewolucja i jej prawidtowości, „Turyzm/Tourism", 24/1, s. 39-47.

LUTYŃSKA K., 1997, Wptyw ankieterski w pierwszej fazie badań kwestionariuszowych , "Ask”, 1.

LUTYŃSKI J., 1972, Analiza procesu otrzymywania informacji w badaniach $z$ zastosowaniem wywiadu kwestionariuszowego, [w:] Analizy i próby technik badawczych w socjologii, t. 4, Zakład Narodowy im. Ossolińskich we Wrocławiu, Wrocław, s. 13-125.

NAWOJCZYK M., 2002 Przewodnik po statystyce dla socjologów, SPSS Polska, Kraków.

NIEDBALSKI J., 2013, Odkrywanie CAQUDAS. Wybrane bezptatne programy komputerowe wspomagajace analizę danych jakościowych, Wyd. Uniwersytetu Łódzkiego, Łódź.

NOGA-BOGOMILSKI A., 2007, Specyfika wybranych metod zbierania danych w badaniach ilościowych, [w:] D., Maison, A. Noga-Bogomilski (red.), Badania marketingowe. Od teorii do praktyki, GWP, Sopot.

NOWACKI M., 2010, Jakość produktu atrakcji turystycznych a zadowolenie, korzyści i zamiary zwiedzajaccych: weryfikacja modelu, „Turyzm/Tourism”, 20/1, s. 21-36.

OsTASIEWICZ W., 2012, Myślenie statystyczne, Woltes Kluwer, Warszawa.

PARZYCH K., 2010, Determinanty aktywności turystycznej młodzieży szkolnej na przykładzie młodzieży licealnej Stupska i Częstochowy, „Turyzm/Tourism”, 20/1, s. 37-43.

PRZYBYŁOWSKA J., 1978, Wywiad swobodny ze standaryzowaną listą poszukiwanych informacji i możliwości jego zastosowania w badaniach socjologicznych, "Przegląd Socjologiczny”, 30, Zakład Narodowy im. Ossolińskich we Wrocławiu, Wrocław, s. 54-68.

RYDZ E., 2014, Zróżnicowanie przestrzeni turystycznej Pomorza środkowego, , „Turyzm/Tourism”, 24/1, s. $73-80$.

SCHUMAN H., 2013, Metoda i znaczenie w badaniach sondażowych, Oficyna Naukowa, Warszawa.

SOBOTKA S., 2014, Próba wyznaczenia obszarów o najwyższym stopniu wykorzystania turystycznego jako przestanki do regionalizacji turystycznej Polski, , „Turyzm/Tourism”, 24/2, s. 35-43.

SOKOŁOWSKI D., 2014, Rozwój turystyki w gminie nadmorskiej w świetle danych obiektywnych $i$ opinii jej mieszkańców: przykład gminy Krokowa, "Turyzm/Tourism”, 24/1, s. 81-88. 
SZCZECHOWICZ B., 2012, Wykorzystanie koncepcji produktu w analizie związków turystyki i kultury fizycznej, „Turyzm/Tourism”, 22/2, s. 23-32.

SZLENDAK T., 2015, Ironiczny stosunek do świata, [w:] A. Wódkowski (red.), Badania marketingowe rocznik PTBRiO 2014/2015, http://www.ptbrio.pl/images/stories/Rocznik_2015/ironiczny_ stosunek_do_swiata.pdf.

SZTABIŃSKI P.B., 1996, Ankieter jako źródło sugestii, „Przegląd Socjologiczny”, 45.

ŚWIECA A., BRZEZIŃSKKA-WÓJCIK T., JÓŹWIK M.J., KRUKOWSKA R., SKOWRONEK E., TUCKI A., 2014, Wybrane aspekty przestrzeni turystycznej Lubelszczyzny, „Turyzm/Tourism”, 24/1, s. 89-96.

WIECZORKOWSKA-WIERZBIŃSKA G., 2005, Statystyka: woprowadzenie do analizy danych sondażowych $i$ eksperymentalnych, Wyd. Naukowe Scholar, Warszawa. 